\title{
Os 70 anos da Universidade de São Paulo e a questão orçamentária
}

Como é sabido dos leitores da REEUSP, a Universidade de São Paulo está comemorando 70 anos, tema que vem sendo tratado nos dois editoriais de 2004. Os seus números são impressionantes. Alguns expressam a sua dimensão física e estrutural. A área dos campi é de 74,5 milhões de $\mathrm{m}^{2}$, com 1,4 bilhão de $\mathrm{m}^{2}$ de área edificada. Possui 36 unidades de ensino, que entre os cursos de graduação e os programas de mestrados e doutorados somam 72.867 alunos. Conta, ainda, com 4.884 professores e 14.900 funcionários. Outros números também expressam a sua contribuição social e científica. Presta atividades assistenciais à população, por meio dos seus hospitais, totalizando 16.050 internações, 206.953 atendimentos de emergência e 133.989 atendimentos ambulatoriais. Promove por ano cerca de 9.767 eventos científicos e culturais e mais de mil cursos extracurriculares. Forma, em média, 4.600 novos profissionais em cursos de graduação e titula $30 \%$ dos doutores do país. Segundo o ISI (Instituto para Informação Científica), dos EUA, ela ocupa $027 .^{\circ}$ lugar entre as mais de 5.000 universidade do mundo em relação à produção de artigos científicos. Seus docentes e alunos recebem premiações e outras distinções no Brasil e no exterior.

No entanto, se esses números expressam sua importância e nos orgulham, outros números nos preocupam. Com um orçamento de $\mathrm{R} \$ 1,575$ bilhão para 2004, 87\% desse total está comprometido com o salário dos professores, funcionários e aposentados. Há necessidade de mais verbas para manter e ampliar o ensino e a pesquisa. Diante disso, abre-se um debate não só para a USP, mas para toda a sociedade, sobre aumentar o financiamento estatal ou criar outras fontes para custear a manutenção dessa máquina colossal de ensino e pesquisa.

Alguns afirmam que o Estado não pode aumentar o financiamento do ensino superior, e que, por isso, devem ser criados mecanismos para captação de recursos junto à iniciativa privada. Outros defendem a cobrança de mensalidades dos alunos com renda familiar suficiente para pagar seus estudos e outros dizem que os alunos já pagam por meio dos impostos e, por isso, deve haver maior contribuição do Estado. A discussão está aberta, o passado e o presente da USP estão firmados, mas precisamos cuidar do seu futuro. A dimensão econômica não pode ameaçá-lo. A contribuição da Universidade para o desenvolvimento científico, cultural e social do país é imensurável. Assim, nenhuma nação pode permitir que um bem cultural e científico tão valioso do seu patrimônio seja ameaçado.

Para aqueles que criticam os altos gastos gerados pelas universidades públicas, deixamos a resposta de um Reitor da Universidade de Harvard, quando o Presidente Roosevelt fez crítica aos altos gastos com a educação: "Se o Senhor acha cara a educação, porque não tenta a ignorância". Nós, brasileiros já pagamos um alto preço por isso.

Esta número 3 apresenta dois trabalhos sobre adesão. Um feito com enfermeiros de 15 instituições da cidade de São Paulo, visando identificar os condicionantes institucionais e individuais para a adesão do trabalhador de Enfermagem às precauções/isolamento na assistência. Infelizmente, com esse estudo percebe-se que algumas instituições utilizam precauções inadequadas, ultrapassadas e distintas das recomendadas pelos órgãos governamentais! O outro trabalho avalia a adesão dos doentes com dor crônica não oncológica ao tratamento e identifica as relações entre a crença de controle da saúde e a adesão. Detectaram-se altos índices de adesão parcial e não adesão ao tratamento, e doentes com crenças de maior "internalidade" aderiram menos ao tratamento.

O papel do parceiro sexual no suporte social na reabilitação da mulher mastectomizada foi pesquisado em nove parceiros de mulheres nessa condição, no interior de São Paulo.

Um estudo de intenção epistemológica, acerca da Teoria do Alcance de Metas de Imogene King e suas contribuições para o conhecimento e prática de enfermeiros que atuam no Programa Saúde da Família (PSF), também está presente na reflexão feita pelas colegas do Ceará. 
Este número apresenta o processo de formação de cultura organizacional em um hospital filantrópico da cidade de São Paulo; o significado do trabalho em equipe na reabilitação de pessoas com malformação craniofacial congênita (um estudo que visou refletir o fenômeno engendrando convergências e divergências, destacando a explicitação das diferenças e aprendizado contínuo); a percepção de crianças hospitalizadas, em idade escolar, sobre a realização de exames (as crianças cooperam com os exames apesar do medo, por perceberem que eles fazem parte do tratamento) e os diagnósticos de Enfermagem presentes em 17 pacientes no período pré-operatório de cirurgia cardíaca.

A preocupação com os custos na área de Enfermagem aparece em dois artigos: um que aborda o ensino de custos nas escolas de graduação em Enfermagem, em pesquisa com 28 docentes; e outro que apresenta um modelo de planilha de custos utilizada no treinamento e desenvolvimento de pessoal de Enfermagem em uma organização hospitalar.

Quanto aos dois últimos artigos deste número, não menos importantes, o primeiro registra que, apesar da busca da integralidade do ser humano, presente nos discursos da Enfermagem, a formação do enfermeiro enfatiza a dimensão técnica e pouco possibilita o crescimento interno do profissional; o segundo apresenta a experiência do desmame em mulheres de uma mesma família, verificando que o discurso dos formadores de política sobre o aleitamento materno parece influenciar bastante na construção dessa prática, atuando mais que as de gerações anteriores da família.

Esperamos que essa leitura possa ajudá-lo no seu crescimento, leitor.

Obrigada, mais uma vez, por ela.

Prof. ${ }^{a}$ Dr. ${ }^{a}$ Ana Maria Kazue Miyadahira

Editora
Prof. ${ }^{a}$ Dr. ${ }^{a}$ Valéria Castilho

Membro do Conselho de Editores

Prof. ${ }^{a}$ Dr. ${ }^{\text {a }}$ Maria Júlia Paes da Silva

Presidente do Conselho de Editores 


\section{The 70 years of the University of São Paulo and the budget question}

As the readers of REEUSP know, USP is celebrating its $70^{\text {th }}$ anniversary, a theme that has been dealt on the two editorials of 2004. Its numbers are impressive. Some of them express its physical and structural dimensions. The campuses area has 74.5 million square meters with 1.4 billion square meters of built area. It has 36 teaching units, of which among the undergraduate courses and Master's and Doctorate programs account 72,867 students. It also has 4,884 professors and 14,900 employees. Other numbers also express its social and scientific contributions. It offers assistance activities to the population by its hospitals, totaling 16,050 admissions, 206,953 visits to the emergency department and 133,989 ambulatory attendances. It promotes around 9,767 scientific and cultural events and more than a thousand extracurricular courses per year. It graduates in average 4,600 new professionals in graduation courses and majors 30\% of doctors of the country. According to ISI (Institute for Scientific Information) from the USA, it is on the $27^{\text {th }}$ place among more than 5,000 universities around the world regarding to the production of scientific articles. Its teaching staff and students receive prizes and other distinctions in Brazil and abroad.

However, if these numbers express its importance and make us proud, other numbers worry us. With a budget of $R \$ 1,575$ billion for $2004,87 \%$ of the total is due to the salary of the professors, employees and the retired ones. There is a need of higher funds to keep and improve teaching and research. Thereby, a debate is open not only to USP, but to the whole society for increasing the state financing or creating new sources for decreasing the expenses of this huge machine of teaching and research.

Some people affirm the government can't increase the finance of superior teaching and, for this reason, mechanisms must be created in order to capture resources from private initiative. Others advocate the charge of payment from students with family income enough to pay their studies; and others say the students already pay through taxes and, for that, there must be more contribution from the government. The discussion is open, the past and present of USP are firmed, but we need to look after its future. The economic dimension can threat it. The contribution of the university for the scientific, cultural and social development of the country is immeasurable. Therefore, no nation can allow a cultural and scientific good so valuable of this heritage be in risk.

For those who criticize the high expenses generated by public universities, we leave the answer form a dean of Harvard University when president Roosevelt criticized his expenses on education: "If you think the education is expensive, why don 't you try ignorance?" We, Brazilians, pay high for that.

This issue number 3 presents a work made with nurses from 15 institutions in Sao Paulo city, focusing on identifying the institutional and individual conditioners for the nursing workers' adherence to precautions/isolation on care. Unfortunately, by this study, it was perceived that some institutions use inadequate, outdated and different precautions form those recommended by governmental agencies.

Another study still concerning adherence, which evaluates the compliance of patients with non-oncologic chronic pain to the treatment and identifies the relationships between beliefs of health control and compliance, detected a high rate of partial compliance and non-compliance with the treatment and patients with higher "internality" beliefs were less compliant with the treatment.

The role of the sexual partner on the social support for the rehabilitation of mastectomized women was researched in 9 partners of women in this condition in the countryside of Sao Paulo. A study of epistemological intention about the Imogene King's goal achievement theory and its contribution for knowledge and practice of nurses who work in the family health Program (FHP) is also present on the reflection made by colleagues from Ceará.

This issue presents the process of organizational culture formation in a philanthropic hospital in Sao Paulo City, the meaning of team work in the rehabilitation of people with congenital craniofacial malformation (a study that sought to reflect the phenomenon engendering convergences and divergences, outlining to express the differences and continuous learning), the perception of hospitalized children in school age on the exam accomplishment (children cooperate with the exams despite the fear for noting them as part of their treatment) and the nursing diagnosis on 17 patients in the preoperatory period of cardiac surgery. 
The concern on the costs in the nursing area is present in two articles: one which involves cost teaching in graduate nursing schools surveying 28 professors; the other one presents a spreadsheet cost model used for training and development of nursing staff in a hospital organization.

The last two articles in this issue, last but not least, show on the first one that, in spite of the search for the integration of the human being presented on nursing discourses, it was observed that the nurse professional formation emphasizes the technical dimension and gives few possibilities for the professional's internal growth. On the second one, the weaning experiences among women from the same family, it was verified that policymakers' discourses on breast-feeding seem to influence a lot on this practice, working better than the previous generations of the family.

We hope we can help you on your self-growth.

Once more, thank you for your reading. 


\section{Los 70 años de la Universidad de São Paulo y la cuestión presupuestaria}

Como es de conocimiento de los lectores de la REEUSP, la USP está conmemorando 70 años tema que viene siendo tratado en dos editoriales del 2004. Sus números son impresionantes. Algunos expresan su dimensión física y estructural. El área del campus es de 74.5 millones de $m^{2}$, con 1.4 billón de $m^{2}$ de área construída. Posee 36 unidades de enseñanza, que entre los cursos de pre-grado y los programas de maestría y doctorado suman 72,867 alumnos. Cuenta, aún, con 4,884 profesores y 14,900 administrativos. Otros números expresan, también, su contribución social y cientifica. Presta actividades asistenciales a la población, por medio de sus hospitales, totalizando 16,050 internamientos, 206,953 atenciones de emergencia y 133,989 atenciones en consulta externa. Promueve por año cerca de 9,767 eventos científicos y culturales y más de 1,000 cursos extracurriculares. Gradúa, en promedio, 4,600 nuevos profesionales en el pre-grado y titula 30\% de los doctores del país. Según el ISI (Instituto para Información Cientifica), de los EUA, ella ocupa el $27^{0}$ lugar entre las más de 5,000 universidades del mundo en relación a la producción de artículos científicos. Sus docentes y alumnos reciben premios y otras distinciones en Brasil y en el exterior.

No obstante, si bien es cierto que esos números expresan su importancia y nos enorgullecen, otros nos preocupan. Con un presupuesto de $R \$ 1,575$ billón para 2004, 87\% de ese total está comprometido con el sueldo de los profesores, administrativos y jubilados. Hay necesidad de más presupuesto para mantener y ampliar la enseñanza y la investigación. Frente a esto, se abre un debate no sólo para la USP, sino también para toda la sociedad, sobre aumentar el financiamiento estatal o crear otras fuentes para costear la manutención de esa colosal máquina de enseñanza e investigación.

Algunos afirman que el Estado no puede aumentar el presupuesto para la enseñanza superior, y que, por eso, deben ser creados mecanismos para la captación de recursos con ayuda de la iniciativa privada. Otros defienden el cobro de mensualidades a los alumnos con ingreso familiar suficiente para pagar sus estudios y otros dicen que los alumnos ya pagan por medio de los impuestos y, por eso, debe haber mayor contribución del Estado. La discusión está abierta, el pasado y el presente de la USP están firmados, sin embargo precisamos cuidar de su futuro. La dimensión económica no puede amenazarla. La contribución de la Universidad para el desarrollo cientifico, cultural y social del país es inmensurable. Así, nadie puede permitir que un bien cultural y científico tan valioso de su patrimonio sea amenazado.

Para aquellos que critican los altos gastos generados por las universidades públicas, dejamos la respuesta de un Rector de la Universidad de Harvard, cuando el Presidente Roosevelt hizo una crítica a los altos gastos con la educación: "Si ud halla cara la educación, por qué no intenta la ignorancia?". Nosotros, brasileños ya pagamos un alto precio por eso.

Este número 3 presenta un trabajo realizado con enfermeros de 15 instituciones de la ciudad de São Paulo, visando identificar los condicionantes institucionales e individuales para la adhesión del trabajador de Enfermería a las precauciones/aislamiento en la asistencia. Lamentablemente, con este estudio se percibe que algunas instituciones utilizan precauciones inadecuadas, ultrapasadas y distintas de las recomendadas por los órganos gubernamentales!

Otro estudio aún sobre adhesión que evalúa la adhesión de los enfermos, con dolor crónico no oncológica, al tratamiento e identifica las relaciones entre la creencia de control de la salud y la adhesión, detectó altos índices de adhesión parcial y no adhesión al tratamiento y que, enfermos con creencias de mayor "internalidad" se adhirieron menos al tratamiento.

El papel del compañero sexual en el soporte social en la rehabilitación de la mujer mastectomizada fue investigado en nueve compañeros de mujeres en esa condición, en el interior de São Paulo. Un estudio de intención epistemológica acerca de la Teoría del Alcance de Metas de Imogene King y sus contribuciones al conocimiento y práctica de enfermeros que actúan en el Programa Salud de la Familia (PSF), también está presente en la reflexión realizada por las colegas de Ceará.

Este número presenta el proceso de formación de la cultura organizacional en un hospital filantrópico de la ciudad de São Paulo, el significado del trabajo en equipo en la rehabilitación de personas con malformación 
craneofacial congénita (un estudio que visó reflexionar sobre el fenómeno, engendrando convergencias y divergencias, destacando la explicación de las diferencias y aprendizaje continuo), la percepción de niños hospitalizados, en edad escolar, sobre la realización de exámenes (los niños cooperan con los exámenes a pesar del miedo, por percibirlos como parte del tratamiento) y los diagnósticos de Enfermería presentes en 17 pacientes en el período pre operatorio de cirugía cardiaca.

La preocupación con los costos en el área de Enfermería aparece en dos artículos: uno que aborda la enseñanza de costos en las escuelas de pre grado en Enfermería, en investigación realizada con 28 docentes; y en otro que presenta un modelo de planilla de costos utilizada en el entrenamiento y desarrollo del personal de Enfermería en una organización hospitalaria.

Los dos últimos artículos de este número, mas no menos importantes, muestran, en el primero, que a pesar de la búsqueda de la integralidad del ser humano, presente en los discursos de Enfermería, se observa que la formación del enfermero enfatiza la dimensión técnica y posibilita poco el crecimiento interno del profesional; y en el segundo, la experiencia del desmame en mujeres de una misma familia, permite verificar que el discurso de los formadores de política sobre la lactancia materna parece influenciar mucho en la construcción de esa práctica, actuando más que las de generaciones anteriores de la familia.

Esperamos que esta lectura, apreciado lector, pueda ayudarlo en su crecimiento.

Gracias, una vez más, por ella. 